\title{
ORGANIZATIONAL BENEFITS OF COMMUNITIES OF PRACTICE: A TWO-STAGE INFORMATION PROCESSING MODEL
}

\author{
KATJA ZBORALSKI \\ Berlin University of Technology, Institute for \\ Technology and Management, Chair for Innovation \\ and Technology Management, Berlin, Germany
}

\section{SOEREN SALOMO}

Karl-Franzens University Graz, Institute for Technology and Innovation Management, Graz, Austria

\section{HANS GEORG GEMUENDEN}

\author{
Berlin University of Technology, Institute for \\ Technology and Management, Chair for Innovation \\ and Technology Management, Berlin, Germany
}

The concept of Communities of Practice (CoPs) has been recognized as a means to foster knowledge sharing and learning in organizations. In this article, we first address the challenge of measuring the value of CoPs. Second, we develop and test a two-stage information processing model including information generation through $\mathrm{CoP}$ participation and information processing into the organization. An enhanced network position of CoP-members in relation to the primary organization is identified as a critical means to facilitate information processing. We analyze data from 222 community members from different communities of a multinational company, using partial least square structural equations modeling.

Address correspondence to Katja Zboralski, Berlin University of Technology, Institute for Technology and Management, Chair for Innovation and Technology Management, Str. des 17, Juni 135, Sekr. H 71, Berlin 10623, Germany. E-mail: katja.zboralski@tim. tu-berlin.de 


\section{INTRODUCTION}

An organization's ability to innovate is the basis for long-term growth and competitiveness. Resulting from radical changes in their business environment, most companies face the challenge to develop, acquire, and modify knowledge for developing new products and services. Hence, the ability to strategically leverage knowledge has become a crucial factor for global competitiveness (Drucker 1993; Kogut and Zander 1992; Nonaka and Takeuchi 1995). Consequently, more and more organizations implement knowledge management systems to use resource knowledge more effectively and efficiently (Davenport and Prusak 1998; Probst et al. 1999). In this context, the concept of a Community of Practice $(\mathrm{CoP})$ has recently gained high attention from practitioners and scholars alike (e.g., Lindkvist 2005; Swan et al. 2002; Thompson 2005; Wenger et al. 2002). This is based on the fact that knowledge networks like CoPs are increasingly seen as central means to foster and enhance knowledge sharing and learning in organizations (Brown and Duguid 1991; Lesser and Storck 2001); processes crucial for innovation (Leonard-Barton 1995).

Research investigating CoPs is so far mostly based on qualitative case studies (e.g., Dubé and Bourhis 2005; Gherardi et al. 1998; Gongla and Rizzuto 2001; Kimble and Hildreth 2005; Wenger 1998b). Even though the number of CoPs in organizations has grown significantly over the last years, little is known about the specific performance impact of communities of practice. As a consequence, the research question addressed by this article is as follows: What are the critical activities within CoPs, and how do these translate into organizational-level performance effects?

By answering these questions, our study contributes to $\mathrm{CoP}$ and knowledge management research in three important ways. First, we analyze CoP effects on the organizational level. We argue that one has to consider the primary task of community members in order to evaluate organizational-level performance effects. Performance of the primary organizational unit is understood as the extent to which knowledge generated within a CoP helps to improve the primary task of the organization. Second, we acknowledge that-from an information-processing point of view-both information generation through CoP participation and processing this information into the primary task organization are vital for CoP success. Through a path model, we are able to explicitly 
examine how network position mediates the relationship between CoP activities and success. Finally, we contribute to the knowledge management literature by employing multiitem measures for the constructs of our model. This approach increases the reliability of our results and opens up further empirical research-testing performance effects in the context of CoPs.

\section{RESEARCH FRAMEWORK}

\section{Communities of Practice for Information Generation and Processing}

Originally introduced in the context of Lave and Wenger's research toward a "social theory of learning" (Lave and Wenger 1991), the increasing popularity of the concept in corporate practice brought about various interpretations of the term. Generally, a CoP can be defined as a group of people in an organization who interact with each other across organizational units or even across organization boundaries due to a common interest or field of application (e.g., Snyder 1997; Wenger and Snyder 2000). Their objective is to learn and support one another in order to create, spread, retain, and use knowledge relevant to the organization. Initially, CoPs were understood as self-emerging and selforganizing networks in which everyone can participate (Wenger 1998b). Current practice, however, shows that organizations strategically support existing (informal) networks and deliberately establish CoPs with managed memberships (Storck and Hill 2000). Particularly, multinational companies in knowledge-intensive industries apply the CoP concept (APQC 2000; Hildreth et al. 2000).

Reviewing existing CoP definitions, some key activities can be identified as a common denominator of CoPs. CoPs are characterized by the collaboration and exchange of information, knowledge, and experiences in order to learn and to generate both new knowledge and "common practices" (Lesser and Storck 2001; McDermott 1999; Stewart 1996; Wenger 1998a). A necessary prerequisite for knowledge sharing is an existing network of experts and people interested in the subject organized in their CoP. Hence, CoPs are further characterized by activities aimed at establishing, extending, and maintaining relationships between individual members (Henschel 2001; North et al. 2004; Schoen 2001), e.g., establishing contacts between different $\mathrm{CoP}$ members and organizing informal meetings to support mutual information exchange. Thus, 
we propose that two different kinds of activities can be found in communities: (1) content-related activities of information exchange, including the search for and the delivery of information; and (2) metaactivities concerned with organizing the CoP work in terms of creating possibilities for networking among community members.

While most previous research focuses these CoP internal activities, we suggest that $\mathrm{CoP}$ activities are more comprehensively described as a two-stage information process. Besides pertaining to a $\mathrm{CoP}$, each member is part of a formal organizational unit that fulfils a specific task- the primary task performed within the primary organizational group. Thus, community "internal" activities of information exchange and networking can be characterized as activities performed in a secondary group. These internal activities are often informal in nature and meant to support primary task activities. Participation in a CoP enables members to access information, share experiences, and learn from colleagues in other organizational units (Seufert et al. 1999). Following such first-stage information gathering, CoP members process the information acquired through their CoP participation to their "primary" organizational unit. Hence, new information, knowledge, and expertise generated within the $\mathrm{CoP}$ are communicated to noncommunity members (Gongla and Rizzuto 2001). This two-stage information process is similar to the technological gatekeeper concept introduced in the context of innovation management by Allen (1967; see also Macdonald and Williams 1993). Equivalent to technological gatekeepers, CoP members can be identified as key persons for information and knowledge transfer. They are well integrated into two networks: an external network of information sources-i.e., the $\mathrm{CoP}$ - and an internal network within their "primary" organization to which they ideally pass on the information (Allen et al. 1971; Taylor 1975; Tushman and Scanlan 1981). Accordingly, CoP members also can be understood as having two main functions from the perspective of their "primary" organizational unit (Domsch et al. 1989): On the one hand, they are "information producers" who gather, collect, accumulate, and place this information at colleagues' disposal. On the other hand, they are "information catalysts" who translate and encode information before transferring it, set up contacts with experts, and pass on tips on information sources. Indirectly, CoP members foster socialization processes within their work units (Tushman and Katz 1980).

In order to explain the performance effects of CoPs, our framework includes four hypothesized relationships: The first hypothesis, H1, 


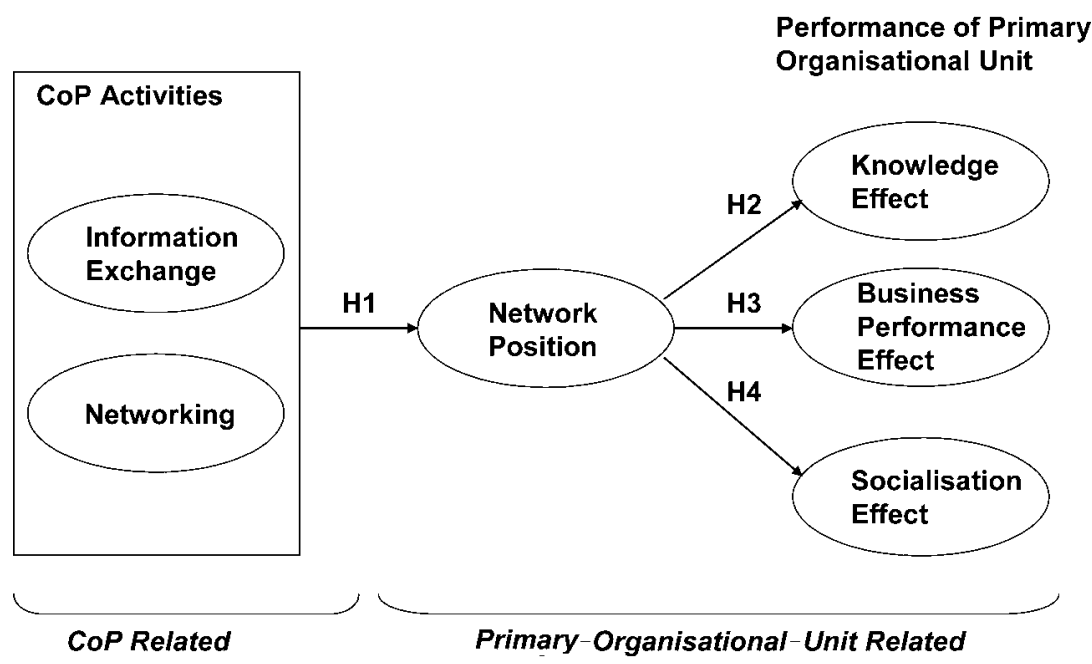

Figure 1. Performance effects of CoPs-a two-stage information processing model.

addresses the interrelation of different $\mathrm{CoP}$ "internal" activities and possible effects on the network position of the individual CoP member in relation to the primary organization. The hypotheses $\mathrm{H} 2$ to $\mathrm{H} 4$ are concerned with the relationship of the network position and primary organization-level performance. Together, these hypotheses suggest that network position mediates the relationship between CoP activities and success. The path model with the hypothesized relationships is shown in Figure 1.

\section{The Impact of Communities of Practice Activities on the Individual Member Network Position}

Although CoPs have been established in several organizations, their value to the organization is still a subject of significant dispute. Particularly, the question of how to measure the benefits arising from CoPs is addressed (McDermott 2002). Evaluating community outcomes in terms of financial ratios is rather difficult (Schoen 2001). Effects can not always be directly linked to activities of the $\mathrm{CoP}$ but could also result from other contextual factors. Moreover, effects may only become apparent after a certain time lag. Besides, due to the nature of $\mathrm{CoP}$ activities, most community outcomes are intangible assets and, therefore, difficult to measure (Adler and Kwon 2002; Bontis and Choo 2002; Carmeli 2004). Further, assessing the exact costs of a community is challenging. 
They consist not only of technology-related investments, but of costs for participation in the community (opportunity costs, salaries, and incentives); costs directly related to meetings; costs for maintaining the technical infrastructure; and costs for content publishing, promotional material, etc. (Millen et al. 2002). Consequently, assessing the overall value of community activities remains a difficult task.

We suggest an alternative approach to assessing the performance of CoPs that is based on our understanding of the CoP related two-stage information process. Ultimately, participation in a CoP should result in an improved performance of the primary task. Hence, organizational members active in a CoP should gain specific competencies, which again should enable them to better perform their primary task (Gongla and Rizzuto 2001; North et al. 2004). As our concept of CoPs also requires information processing into the primary organizational unit, such individual competence gains should result in better work performance of the overall primary organizational unit. Further, we suggest that the effect of community activities on the primary task performance is mediated by an improved network position of the CoP member.

Due to their community participation, members increase their access to new sources of knowledge (Lesser and Storck 2001). By interacting within a CoP, existing knowledge is reused and modified and, by that, transformed into new knowledge (Lesser and Prusak 1999; Wenger 1998b). Thus, the exchange and combination of personal knowledge and the networking activities between CoP members, as central activities of CoPs, result in increased learning and knowledge creation (Kogut and Zander 1992; Nahapiet and Ghoshal 1998). Consequently, each individual member is able to improve existing competencies and gain new competencies (APQC 2000). However, CoP members may show varying intensities of participation in information exchange (Wenger and Snyder 2000). Relatively more intensive search activities may lead to a better understanding of the respective search subject and directly improve the competence stock of the searching $\mathrm{CoP}$ member. Additionally, CoP members actively delivering, structuring, and evaluating existing knowledge may also experience improved competencies. They may learn from the information demands of others; delivering information may trigger a learning process as others, e.g., add complementary knowledge, and activities related to structuring and evaluating information may focus CoP information exchange on areas most relevant for the individual competence base. From a general perspective, CoP theory is mainly a 
theory about learning as socialization (Lave 1993). Increasing participation within the $\mathrm{CoP}$ is the key to identity formation and learning (Fox 2000). Hence, metaactivities aimed at establishing contacts between different $\mathrm{CoP}$ members and organizing the CoP information flow should improve CoP-related information processing. Overall, the level of expertise should increase. Further, individual members facilitating CoP internal networking become central figures in the CoP and increase their probability of gaining new insights from other CoP members (e.g., Saint-Onge and Wallace 2003).

Overall, participation in CoPs will signal an expert status to others in the primary organization. As experts can be expected to deliver valuable information concerning the primary task, CoP members will gain a more prominent network position (APQC 2000; Wasko and Faraj 2000). Other members from the primary organization will more often contact active CoP members with work-related questions. Further, as CoP participation should increase awareness for critical information and open sources for new information, individual CoP members may engage more actively in distributing such information to their primary organization colleagues (McDermott 1999). Hence, we expect the network position of $\mathrm{CoP}$ members with regard to their primary organization to improve with increased levels of CoP-related activities.

Hypothesis 1. CoP members who participate strongly in information exchange and networking activities within the CoP will experience a stronger network position related to the primary organization than less-active CoP members.

\section{The Effect of Enhanced Network Position on the Performance of the Primary Organizational Unit}

The current literature emphasizes CoPs as forums for shared learning and instruments to increase organizational capabilities (Brown and Duguid 2001; Hedberg and Holmquist 2001; Snyder 1997). This is mainly based on the fact that community activities enhance the externalization of knowledge. Especially close and intense communication among community members foster the transfer of "hitherto" -tacit knowledge, which has been identified as a central mode of knowledge creation and a source of competitive advantage (Leonard and Sensiper 1998; Nonaka 1994). CoPs support the creation of a common knowledge base by connecting different knowledge domains across the organization (Sawhney and Prandelli 2000; Wenger and Snyder 2000). Existing know-how is improved, and new 
organizational competencies are developed (Tsai and Goshal 1998). CoPs may exhibit a climate that may stimulate creativity through open communication and an exchange of interdisciplinary knowledge (Perry-Smith and Shalley 2003; Storck and Hill 2000). Members are encouraged to articulate new ideas and "think outside of the box" (Millen et al. 2002). Due to the free revealing of ideas and solutions, these solutions can be advanced by other community members (Harhoff et al. 2003; von Hippel 2005). Thus, CoPs may enhance the creative capacity and, thereby, the innovative capabilities of an organization (Brown and Duguid 1991; Saint-Onge and Wallace 2003). As we previously argued, the positive effects of participating in a CoP need to be applied in the context of the primary organizational task. This requires knowledge to be transferred to other members of the primary organizational unit in order to extend these effects beyond the individual CoP member. Hence, information processing into primary organizational units by the CoP members is needed. We suggest the network position of the CoP member to mediate the relationship of intensive $\mathrm{CoP}$ activities and primary task performance. Generally, CoP members with a stronger network position should be better able to transfer knowledge gained through their CoP participation to their colleague in the primary organizational units (Tsai 2001). Such knowledge transfer may have different performance effects at the primary organizational level (Inkpen and Tsang 2005).

First, CoP participation and subsequent knowledge transfer may have a knowledge effect: Existing knowledge becomes more visible; the externalization of knowledge helps preserving knowledge of employees leaving the company; knowledge gained from experiences is documented (Wenger 1998b); and experiences (positive and negative) are shared and made "public" by the communication of "best-practices" and "lessons learned" (Wenger and Snyder 2000). Overall, as CoPs are mainly focused on sharing and creating knowledge, the knowledge base at the primary organizational unit should also be improved.

Second, transferring knowledge from the CoP to the primary organizational unit may have a business performance effect: Knowledge gained from participation in CoPs may be used to improve business processes at the primary organization level (Schoen 2001). Best-practice solutions are easier and faster accessed and transferred to operations, which may enhance productivity (Millen et al. 2002; Saint-Onge and Wallace 2003). As previously discussed, innovation-enhancing effects of CoP participation may also occur (Brown and Duguid 1991). CoP members gain new insights, are challenged by their expert counterparts from other 
organizational units, and may transfer this knowledge as well as an attitude of openness to their colleagues (Lesser and Everest 2001). Further, directly and indirectly gaining access to experts from different organizational units may facilitate "cross-organizational" knowledge sharing and integration. More intensive innovation activity at the primary organizational level may be supported (Burt 2003). Innovation related to improved processes or improved products may enhance business performance as it allows efficiency and effectiveness gains compared to the status quo.

Third, by integrating organizational members into CoPs, organizational units are linked with each other. This may change the existing organizational culture in a favorable way (Saint-Onge and Wallace 2003). On the one hand, the development of collective sense making, a common language, as well as the emergence of networks among members affect the culture. On the other hand, people's attitudes toward knowledge sharing also outside the CoP may change as such activity is openly approved and rewarded. With a CoP member as a part of the primary organizational unit, cooperation between staff and the level of trust between staff may be strengthened (McDermott 2002). Hence, information processing into the primary organizational unit may also support socialization processes at this level.

In sum, we hypothesize that enhanced network position through participation in CoPs improves the performance of the primary organizational unit along different dimensions:

Hypothesis 2. CoP members with a stronger network position through CoP participation will have a positive effect on the knowledge base of their primary organizational units.

Hypothesis 3. CoP members with a stronger network position through CoP participation will have a positive effect on the business performance of their primary organizational units.

Hypothesis 4. CoP members with a stronger network position through CoP participation will have a positive effect on the socialization between the staff of their primary organizational units.

\section{METHODS}

\section{Sample and Data Collection Procedures}

To answer our research questions and test the proposed conceptual model, we conducted an empirical study in a major German multinational 
company. This company started to implement CoPs in 1999 on a grand scale. At the time of our data collection, more than $300 \mathrm{CoPs}$ existed in the company. After several qualitative interviews with experts in order to validate the components of our research model, a questionnaire was developed and successfully pretested with 15 community members of a single community. Existing CoPs were examined regarding their age and number of members. Only communities that were active for more than 6 months and had more than 5 active members qualified for participation in our study; this lead to a population of $220 \mathrm{CoPs}$. Afterwards, the community brokers of the selected CoPs were contacted and asked to participate in the study. Fifty nine brokers agreed to participate and distributed the standardized questionnaire to members of their community. As we could not control to what extent the questionnaire was sent to all community members, an adequate assessment of the response rate was difficult. The data collection took place between July 2003 and November 2003. Finally, 222 member questionnaires from $36 \mathrm{CoPs}$ were returned. Based on the data provided by the brokers, we are able to state that we covered about $31 \%$ of all active community members. Due to the semiformal and dynamic character of CoPs, which makes the assessment of the overall number of CoP members difficult, our sample can be considered a valid representation of the overall population. The respondents have been community members for an average of 21.6 months and spent on average 1 to 2 hours per week on their community activities. The average tenure of the respondents with the company was 11.6 years. The average age of the community was 14.8 months, with an average of 94 members. Neither the duration of participation in the CoP nor the tenure of the respondents was significantly related to the constructs tested in this study. Potential concerns about retrospective bias and common methods variance were in part ameliorated via the instrument development process, which involved careful instrument design in terms of question wording and sequence.

\section{Measures}

To test the hypotheses suggested by the conceptual framework, measures of each construct were developed using multiple items and Likert-type scales $(1=$ not true at all $/$ never to $7=$ completely true/several times a week). Formal pretests were conducted to determine the clarity of the scale items used in the constructs and to obtain preliminary data on 
the hypotheses. In the pretests, 15 community members completed a questionnaire and were involved in follow-up interviews. Their comments and suggestions were incorporated by removing ambiguities and other sources of confusion. All our constructs, as they primarily relate to activities, can be interpreted as an index and are treated as formative constructs (Diamantopoulos and Winklhofer 2001). The measures are briefly discussed below; see the appendix for details.

Information Exchange. Following prior $\mathrm{CoP}$ research, we captured information exchange by seven items that measured the intensity of different activities of searching for and delivering information (Schoen 2001). Thereby, two items regarding the writing of summaries of documents and the declaration of keywords were used to measure specific activities of information delivery. As these two items later proved to be highly correlated, we chose to measure the sixth item as the mean over these two items. This should allow a more reliable assessment of such information delivery activities.

Networking. Networking as a CoP-related metaactivity is concerned with the intensity of activities aiming to establish contacts with other CoP members. It was measured by three items.

Network Position. Network position was measured by six items capturing, e.g., the degree to which members actively transfer gathered information, the intensity of being asked for one's opinion from others outside the CoP, as well as to what extent members build relationships with colleagues.

Performance of Primary Organizational Unit. According to our research framework, three dimensions of performance of the primary organizational unit were differentiated: knowledge effect, business performance effect, and socialization effect. All performance dimensions were multiitem constructs.

\section{Method}

The level of analysis for testing our proposed hypotheses was the individual community member. Thus, all measures reflect members' perception of CoP effects on the organizational performance. A measurement model was applied to establish valid and reliable constructs. To test our proposed hypotheses simultaneously and to account for the multi-dimensionality 
of the factors, we used Partial Least Squares (PLS-Graph 3.0) graph. This procedure defines coefficients of regression between the factors iteratively, and by this manner, it allows us to estimate the model simultaneously (Chin 1998). Generally, we followed the guidelines for constructing indexes based on formative indicators provided by Diamantopoulos and Winklhofer (2001). As formative measurement models are based on linear equation systems, collinearity among indicators of formative constructs would affect the stability of indicator coefficients. Hence, multicollinearity was tested as suggested by Belsley (1991), using SPSS. Thereafter, our formative factors were validated within the PLS model. A bootstrapping procedure allowed assessing the validity of the overall model (Chin 1998).

\section{RESULTS}

Table 1 provides sample statistics as well as correlations between constructs. Details of our measurement model-items used for the constructs with their weights and $t$-values - are reported in the appendix.

\section{Structural Model}

Table 2 reports the results from our path model estimating the main effects of our independent variables on the network position and CoP performance. $\mathrm{R}^{2}$ values between .24 and .45 for the dependent variables of our model suggest that we are able to explain a significant part of the variance. Our Hypotheses 1, suggesting a positive effect of intensity of information exchange and networking activity within the $\mathrm{CoP}$ on network position of CoP members, is only partly supported by our data.

Table 1. Sample statistics and correlations

\begin{tabular}{llllllllll}
\hline Variable & \multicolumn{1}{c}{ Number of items } & Mean & Std. D. & 1 & 2 & 3 & 4 & 5 & 6 \\
\hline 1. & Information exchange & $6(7)^{*}$ & 3.682 & 1.287 & & & & \\
2. & Networking & 3 & 3.441 & 1.569 & .791 & & & \\
3. & Network position & 6 & 4.288 & 1.455 & .478 & .439 & & \\
4. & Knowledge effect & 6 & 4.706 & 1.140 & .289 & .285 & .631 & & \\
5. & Business performance effect & 5 & 4.652 & 1.167 & .330 & .294 & .663 & .729 & \\
6. & Socialization & 2 & 4.022 & 1.644 & .355 & .313 & .670 & .656 & .731 \\
\hline
\end{tabular}

${ }^{*}$ One item is calculated as the mean over two items. 
Table 2. Structural model $-\mathrm{R}^{2}$ values, path coefficients, $\mathrm{t}$-values, and the test of hypotheses

\begin{tabular}{|c|c|c|c|c|c|}
\hline Dependent variable & Predictor & $\mathbf{H}$ & $\begin{array}{c}\text { Path } \\
\text { coefficient }\end{array}$ & t-values & Conclusion \\
\hline \multirow[t]{2}{*}{$\begin{array}{l}\text { Network position } \\
\left(\mathrm{R}^{2}=.238\right)\end{array}$} & Information exchange & H1a & $.350^{*}$ & 3.706 & $\begin{array}{l}\text { H1 partly } \\
\text { supported }\end{array}$ \\
\hline & Networking & $\mathrm{H} 1 \mathrm{~b}$ & .162 & 1.711 & \\
\hline $\begin{array}{l}\text { Knowledge effect } \\
\left(\mathrm{R}^{2}=.399\right)\end{array}$ & Network position & $\mathrm{H} 2$ & $.631^{*}$ & 12.556 & H2 supported \\
\hline $\begin{array}{l}\text { Business performance } \\
\text { effect }\left(R^{2}=.440\right)\end{array}$ & Network position & H3 & $.663^{*}$ & 15.280 & H3 supported \\
\hline $\begin{array}{l}\text { Socialization } \\
\qquad\left(R^{2}=.449\right)\end{array}$ & Network position & $\mathrm{H} 4$ & $.670^{*}$ & 15.119 & H4 supported \\
\hline
\end{tabular}

While intensive information exchange within the community significantly supports the network position of $\mathrm{CoP}$ members regarding the primary organization (.35), such an effect cannot be detected for intensive CoP-internal networking activities. Hypothesis 2, Hypothesis 3, and Hypothesis 4, suggesting a positive relationship between CoP-member network position and organizational level performance dimensions, are all supported by our data (path coefficients between .63 and .67).

\section{DISCUSSION}

The primary objective of this research was to analyze the CoP impact on the organizational level performance. Particularly, we examine how the network position of $\mathrm{CoP}$ members mediates the relationship between $\mathrm{CoP}$ activities and performance. In order to test our hypotheses, we used data from 222 members of 36 communities in a multinational corporation.

As research on CoPs is generally scarce and mainly focused on qualitative case-study research, it is necessary to develop valid and reliable scales for relevant constructs in the CoP context. Our results suggest that $\mathrm{CoP}$ activities can be measured along two dimensions: information exchange covering the content-related activities mainly performed to generate knowledge and networking as a metaactivity in order to establish and sustain a working network. Also, we are able to present a multidimensional measurement of community performance capturing effects of the community for the "host organization" (knowledge effects, 
business performance effect, and socialization effect). Our scales allow a rigorous test of our hypothesis and may also serve as a basis for future research.

As communities of practice are semiformal entities that are part of a formal primary organization, we understand $\mathrm{CoP}$ members to be integrated into two networks: their primary group within in the organization and the semiformal community network. Therefore, we argue that in order to analyze performance effects of $\mathrm{CoP}$ activities, one has to focus the effects regarding the primary task of CoP members. Through CoP participation, members share knowledge and learn. This new knowledge leads to an improved network position with regard to colleagues in the primary task organization. By passing information on to non-community members and applying it when performing their primary task, members positively influence organizational performance. Thereby, especially the network position, which is improved by information exchange and networking within the $\mathrm{CoP}$, enables $\mathrm{CoP}$ members to process information into their primary organizational unit. Hence, from an informationprocessing perspective, CoP-related activities can be understood as a two-stage information process including information gathering in the $\mathrm{CoP}$ as the first stage and information processing toward the primary organization as the second stage. Evidently, network position with relation to the primary task organization plays a central role within this process. It can be regarded as an enabler for possible CoP performance effects.

As this study is based on assessments by community members a common method bias cannot be ruled out. However, it can be reasonably assumed that $\mathrm{CoP}$ members as members of the overall primary organization are sufficiently able to provide an assessment of the effects of CoP activities on the organizational level performance with only limited bias. Regarding the design of the questionnaire, we clearly distinguished between questions related to performance antecedents and $\mathrm{CoP}$ impact on the primary task organizational level by separate sections. This should further reduce potential effects of common source bias.

With regard to further $\mathrm{CoP}$ research, our results emphasize the importance of different community activities and their mediated effects on the organizational-level performance. The primary task of $\mathrm{CoP}$ members needs to be accounted for when analysing performance drivers of CoPs. Here, it is important to examine the mediating role of the network position of CoP members. Our results provide initial evidence for a 
positive relationship of CoP activities and business performance. Further research can build upon these results and validate our findings, which are based on community members' perceptions through, e.g., assessing noncommunity-member performance evaluations. While the performance assessments used in this study mirrors net benefits as perceived by community members, a further extension of our research design could try to differentiate between benefits and costs of CoPs. Specifically, an empirical assessment of differentiated cost dimensions related to CoP activities may allow organizing CoPs in a more efficient way.

In sum, our results suggest that CoPs have the potential to support the development, exchange, and application of knowledge in an organization. Further, our results show that CoPs have a close connection and positive direct impact on business performance. Hence, from a management perspective, supporting CoPs by providing required resources and establishing the necessary prerequisites in the organization seems to be an efficient and effective way of implementing knowledge management.

Appendix. Measurement model

\begin{tabular}{lrr}
\hline Constructs and items & Weights & t-values \\
\hline Information exchange & & \\
If requested, I make my own documents available to other members. & .289 & .893 \\
I arrange access to my knowledge sources for other members. & .170 & .493 \\
I ask for and search for knowledge in the community. & .169 & .814 \\
I assess the knowledge of others with my feedback. & .400 & 1.780 \\
I create documents for the community. & .223 & .883 \\
I write summaries of my documents/ I include keywords in my & .084 & .455 \\
$\quad$ documents. & & \\
Networking & .220 & .700 \\
I set up contact between different community members. & .386 & 1.965 \\
I ask for contact data of other members. & .646 & 2.727 \\
I help organize community meetings and events. & & \\
Network position & .109 & .967 \\
I am happy to tell my colleagues at my workplace about my & & \\
$\quad$ activities in the community. & .212 & 2.036 \\
I tell my supervisors about interesting results from our community. & .378 & 2.850 \\
I have been acknowledged by my work colleagues for my & & \\
$\quad$ participation in the community. & & $\left(C \circ{ }^{\prime}\right.$
\end{tabular}


Appendix. Continued

\begin{tabular}{|c|c|c|}
\hline Constructs and items & Weights & t-values \\
\hline $\begin{array}{l}\text { Because of my involvement in the community, I have been asked } \\
\text { more often for my opinion. }\end{array}$ & .112 & .797 \\
\hline Thanks to the community, I feel more integrated in my company. & .261 & 2.292 \\
\hline $\begin{array}{l}\text { By participating in the community, I have built up relationships with } \\
\text { colleagues. }\end{array}$ & .252 & 2.184 \\
\hline \multicolumn{3}{|l|}{ Knowledge effect } \\
\hline The community has increased our company's expertise. & .287 & 1.651 \\
\hline $\begin{array}{l}\text { Knowledge present in the company is developed further in the } \\
\text { community. }\end{array}$ & .358 & 2.188 \\
\hline $\begin{array}{l}\text { Thanks to the community, the knowledge of employees leaving the } \\
\text { company is not lost. }\end{array}$ & .260 & 1.414 \\
\hline $\begin{array}{l}\text { Through the work of the community, best-practice solutions have } \\
\text { been distributed throughout the company. }\end{array}$ & .246 & 1.460 \\
\hline $\begin{array}{l}\text { Contact with experts is established through the community } \\
\text { members. }\end{array}$ & .100 & .633 \\
\hline $\begin{array}{l}\text { The community serves to evaluate the knowledge present in the } \\
\text { company. }\end{array}$ & .200 & 1.433 \\
\hline \multicolumn{3}{|l|}{ Business performance effect } \\
\hline $\begin{array}{l}\text { The work of the community has allowed processes in the company } \\
\text { to be optimized. }\end{array}$ & .241 & 1.716 \\
\hline $\begin{array}{l}\text { By working in the community, new staff has been able to quickly } \\
\text { find their feet in the subject area. }\end{array}$ & .110 & .556 \\
\hline The community has increased the productivity of its members. & .161 & .801 \\
\hline The ideas of the community have led to innovations. & 681 & 5.607 \\
\hline $\begin{array}{l}\text { The community has improved the use of our company's existing } \\
\text { knowledge. }\end{array}$ & .055 & .321 \\
\hline \multicolumn{3}{|l|}{ Socialization } \\
\hline Through the community, cooperation between staff has increased. & .428 & 1.773 \\
\hline The community has strengthened levels of trust between staff. & .632 & 2.609 \\
\hline
\end{tabular}

${ }^{1}$ Measure was calculated as the mean over the two items.

\section{REFERENCES}

Adler, S. P. and S.-W. Kwon. 2002. Social capital: Prospects for a new concept. Academy of Management Review, 27:17-40.

Allen, T. J. 1967. Communications in the research and development laboratory. Technology Review, 70:31-37.

Allen, T. J., J. M. Piepmeier, and S. Cooney. 1971. International technological gatekeeper. Technology Review, 73:36-43. 
American Productivity and Quality Center (APQC). 2000. Building and sustaining communities of practice: Final report. Houston, TX: American Productivity \& Quality Center.

Belsley, D. A. 1991. Conditioning diagnostics: Collinearity and weak data in regression. In Wiley Series in Probability and mathematical statistics. New York: John Wiley \& Sons.

Bontis, N. and W. C. Choo. 2002. The strategic management of intellectual capital and organizational knowledge. New York: Oxford University Press.

Brown, J. S. and P. Duguid. 1991. Organizational learning and communities-ofpractice: Toward a unified view of working, learning, and innovation. Organization Science, 2:40-57.

Brown, J. S. and P. Duguid. 2001. Knowledge and organization: A social-practice perspective. Organization Science, 12:198-213.

Burt, R. S. 2003. Social origins of good ideas. Chicago: University of Chicago and Raytheon Company.

Carmeli, A. 2004. Assessing core intangible resources. European Management Journal, 22:110-122.

Chin, W. W. 1998. The partial least squares approach to structural equation modeling. In Modern methods of business research, edited by G. A. Marcoulides. Mahwah, NJ. London: Lawrence Erlbaum Associates. pp. 295-336.

Davenport, T. H. and L. Prusak. 1998. Working knowledge: How organizations manage what they know. Boston: Harvard Business School Press.

Diamantopoulos, A. and H. M. Winklhofer. 2001. Index construction with formative indicators: An alternative to scale development. Journal of Marketing Research, 38:269-277.

Domsch, M., H. Gerpott, and T. J. Gerpott. 1989. Technologische Gatekeeper in der industriellen F\&E. Stuttgart: C.E. Pöschel.

Drucker, P. F. 1993. Post-capitalist society. New York: Harper Business.

Dubé, L. and A. Bourhis. 2005. The impact of structuring characteristics on the launching of virtual communities of practice. Journal of Organizational Change Management, 18:145-166.

Fox, S. 2000. Communities of practice, Foucault, and actor-network theory. Journal of Management Studies, 37:853-867.

Gherardi, S., D. Nicolini, and F. Odella. 1998. Toward a social understanding of how people learn in organizations. Management Learning, 29:273-297.

Gongla, P. and C. R. Rizzuto. 2001. Evolving communities of practice: IBM Global Services experience. IBM Systems Journal, 40:842-862.

Harhoff, D., J. Henkel, and E. von Hippel. 2003. Profiting from voluntary information spillovers: How users benefit by freely revealing their innovations. Research Policy, 32:1753-1769.

Hedberg, B. and M. Holmquist. 2001. Learning in imaginary organizations. In Handbook of organizational learning \& knowledge, edited by M. Dierkes, 
A. Berthoin Antal, J. Child, and I. Nonaka. New York: Oxford University Press. pp. 733-752.

Henschel, A. 2001. Communities of Practice: Plattform für individuelles und kollektives Lernen sowie den Wissenstransfer. Bamberg, Germany: Difo-Druck.

Hildreth, P., C. Kimble, and P. Wright. 2000. Communities of practice in the distributed international environment. Journal of Knowledge Management, 4: 27-38.

Inkpen, A. C. and E. W. K. Tsang. 2005. Social capital, networks, and knowledge transfer. Academy of Management Review, 30:146-165.

Kimble, C. and P. Hildreth. 2005. Dualities, distributed communities of practice, and knowledge management. Journal of Knowledge Management, 9:102-113.

Kogut, B. and U. Zander. 1992. Knowledge of the firm, combinative capabilities, and the replication of technology. Organization Science, 3:383-397.

Lave, J. 1993. Situation learning in communities of practice. In Perspectives on Socially Shared Cognition, edited by L. B. Resnick, J. M. Levine, and S. D. Teasley. Washington, DC: American Psychological Association. pp. 63-82.

Lave, J. and E. Wenger. 1991. Situated learning: Legitimate peripheral participation. Cambridge, UK: Cambridge University Press.

Leonard-Barton, D. 1995. Wellsprings of knowledge: Building and sustaining the sources of innovation. Boston: Harvard Business School Press.

Leonard, D. and S. Sensiper. 1998. The role of tacit knowledge on group innovation. California Management Review, 40:112-132.

Lesser, E. L. and K. Everest. 2001. Using communities of practice to manage intellectual capital. Ivey Business Journal, 65:37-41.

Lesser, E. L. and L. Prusak. 1999. Communities of practice, social capital, and organizational knowledge. Cambridge, MA: IBM Institute for Knowledge Management.

Lesser, E. L. and J. Storck. 2001. Communities of practice and organizational performance. IBM Systems Journal, 40:831-841.

Lindkvist, L. 2005. Knowledge communities and knowledge collectivities: A typology of knowledge work in groups. Journal of Management Studies, 42:1189-1210.

Macdonald, S. and C. Williams. 1993. Beyond the boundary: An information perspective on the role of the gatekeeper in the organization. Journal of Product Innovation Management, 10:417-427.

McDermott, R. 1999. Learning across teams: The role of communities of practice in team organizations. Knowledge Management Review, 2:32-36.

McDermott, R. 2002. Measuring the impact of communities. Knowledge Management Review, 5:26-29.

Millen, D. R., M. A. Fontaine, and M. J. Muller. 2002. Understanding the benefit and costs of communities of practice. Communications of the ACM, 45:69-73.

Nahapiet, J. and S. Ghoshal. 1998. Social capital, intellectual capital, and the organizational advantage. Academy of Management Review, 23:242-266. 
Nonaka, Ikujiro. 1994. A dynamic theory of organizational knowledge creation. Organization Science, 5:14-37.

Nonaka, I. and H. Takeuchi. 1995. The knowledge-creating company: How Japanese companies create the dynamics of innovation. New York: Oxford University Press.

North, K., M. Franz, and G. Lembke. 2004. Wissenserzeugung und -austausch in Wissensgemeinschaften-Communities of Practice. Berlin: Arbeitsgemeinschaft Betriebliche Weiterbildungsforschung e.V.

Perry-Smith, J. E. and C. E. Shalley. 2003. The social side of creativity: A static and dynamic network perspektive. Academy of Management Journal, 28: 89-106.

Probst, G. J. B., S. Raub, and K. Romhardt. 1999. Wissen managen: Wie Unternehmen ihre wertvollste Ressource optimal nutzen. 3rd ed. Frankfurt am Main; Wiesbaden: Frankfurter Allg. Zeitung für Deutschland; Gabler.

Saint-Onge, H. and D. Wallace. 2003. Leveraging communities of practice for strategic advantage. Amsterdam: Butterworth-Heinemann.

Sawhney, M. and E. Prandelli. 2000. Communities of creation: Managing distributed innovation in turbulent markets. California Management Review, 42: 24-54.

Schoen, S. 2001. Gestaltung und Unterstützung von Communities of Practice. München: Herbert Utz Verlag.

Seufert, A., G. von Krogh, and A. Bach. 1999. Towards knowledge networking. Journal of Knowledge Management, 3:180-190.

Snyder, W. M. 1997. Communities of Practice: Combining organizational learning and strategy insights to create a bridge to the 21st century. Cambridge, MA: Social Capital Group.

Stewart, T. A. 1996. The invisible key to success: Shadowy groups called community of practice. Fortune Magazine, 134:173-176.

Storck, J. and P. A. Hill. 2000. Knowledge diffusion through "Strategic Communities." Sloan Management Review, 41:63-74.

Swan, J., H. Scarbrough, and M. Robertson. 2002. The construction of "Communities of Practice" in the management of innovation. Management Learning, 33:477-496.

Taylor, R. L. 1975. Technological gatekeeper. R\&D Management, 5:239-242.

Thompson, M. 2005. Structural and epistemic parameters in communities of practice. Organization Science, 16:151-164.

Tsai, W. 2001. Knowledge transfer in intraorganizational networks: Effects of network positions and absorptive capacity on business unit innovation and performance. Academy of Management Journal, 44:996-1004.

Tsai, W. and S. Goshal. 1998. Social capital and value creation: The role of intrafirm networks. Academy of Management Journal, 41:464-476. 
Tushman, M. L. and R. Katz. 1980. External communication and project performance: An investigation into the role of gatekeepers. Management Science, 26:1071-1085.

Tushman, M. L. and T. J. Scanlan. 1981. Boundary spanning individuals: Their roles in information transfer and their antecedents. Academy of Management Journal, 24:289-305.

von Hippel, E. 2005. Democratizing innovation: users take center stage. Boston, MA: MIT Press.

Wasko, M. M. and S. Faraj. 2000. "It is what one does": Why people participate and help others in electronic communities of practice. Journal of Strategic Information Systems, 9:155-173.

Wenger, E. C. 1998a. Communities of Practice: Learning, meaning, and identity. Cambridge, UK: Cambridge University Press.

Wenger, E. C. 1998b. Communities of practice-Learning as a social system. The Systems Thinker, 9:1-5.

Wenger, E. C., R. McDermott, and W. M. Snyder. 2002. Cultivating communities of practice: A guide to managing knowledge. Boston: Harvard Business School Press.

Wenger, E. C. and W. M. Snyder. 2000. Communities of practice: The organizational frontier. Harvard Business Review, 78:139-145. 
Copyright of Cybernetics \& Systems is the property of Taylor \& Francis Ltd and its content may not be copied or emailed to multiple sites or posted to a listserv without the copyright holder's express written permission. However, users may print, download, or email articles for individual use. 